\title{
Social control of public expenditures in a multilevel principal-agent approach
}

\author{
O controle social dos gastos públicos em \\ uma abordagem de agente principal multinível
}

VALDEMIR PIRES

ANDRÉ SATHLER GUIMARÃES*

\begin{abstract}
RESUMO: Busca-se ampliar o modelo teórico de principal-agente, incorporando a perspectiva de múltiplos níveis e distintas situações típicas de agência e aplicando-se a análise ao controle dos gastos públicos em democracias representativas. Trata-se de discussão teórica, com proposta de intersecção de enfoques metodológicos e análise descritiva-exemplificativa de situação hipotética. O principal resultado é desdobrar o modelo principal-agente, com foco no processo decisório e nas competências de formulação, negociação, articulação, compreensão e implementação. Conclui-se que é possível incorporar elementos que tornem o modelo permeável às idiossincrasias de indivíduos, grupos e sociedades, no que diz respeito ao funcionamento do controle social possível dos gastos públicos.
\end{abstract}

PALAVRAS-CHAVE: administração pública; modelo principal-agente; controle social do gasto público.

ABSTRACT: This study enhances the principal-agent model by incorporating a multilevel perspective and differences among agency situations. A theoretical discussion is developed using a proposed intersection of methodological focuses and a descriptiveexemplificative hypothetical analysis. The analysis is applied to public expenditure social control in representative democracies, and as a result, a principal-agent model unfolds that incorporates a decision-making perspective and focuses on formulation, negotiation, articulation, and implementation competencies. Thus, it is possible to incorporate elements into the principal-agent model to make it more permeable to individual, group, and societal idiosyncrasies with respect to public expenditure social control.

KEYWORDS: public management; principal-agent model; public expenditure social control. JEL Classification: H11.

\footnotetext{
* Respectively, professor e pesquisador do Departamento de Administração Pública da Universidade Estadual Paulista (UNESP); e-mail: pires.valdemir@gmail.com; Coordenador do Mestrado Profissional em Poder Legislativo da Câmara dos Deputados, Brasil; e-mail: andre.sathler@camara.leg.br. Submitted 24/September/2013; Approved: 9/September/2014.
} 
This essay suggests two new procedures for analysis of agency relationships ${ }^{1}$ present in public expenditure controls in representative democracies for the following purposes: 1 . To enrich the traditional principal-agent focus with elements of habitus and practical knowledge as suggested by Monsma (2000) based on the works of Bourdieu (1977) and Giddens (1984); 2. To consider the agency relationship between the governing (elected) and the governed (voters) using developments and steps, that is, under a multilevel principal-agent perspective. The resulting hybrid theoretical-methodological instrument can be used to analyze institutions, mechanisms, systems, processes, instruments, and procedures for social control of public expenditures in representative democracies. Such devices can benefit from the theoretical consistency of the principal-agent theory without constraints presented by empirical situations that the abstractions of an approach based solely on rational choice theory cannot capture and consider ${ }^{2}$.

The remainder of the paper is organized as follows. In the first section, the principal-agent theory is briefly presented ${ }^{3}$ and linked to basic issues of representative democracy, especially those related to budgetary control. At the end of the section, a proposed expansion of the principal-agent model is presented by Waterman and Meier (1998), highlighting how their approach is applied to a multilevel analysis. In the second section, the multilevel principal-agent approach is described using a diagram to understand social control of public expenditures in representative democracies. Each level of the diagram is reviewed using the model of Waterman and Meier (1998). In the conclusion, a summary of the formulated proposal is presented to reinforce its importance and opportunity.

This is an initial effort to build an analytical instrumental both theoretically solid and empirically applicable to evaluate forms of social control (traditional or innovative) for public expenditures in contemporary democratic contexts.

Since the problematization of Mirrlees (1999), treating the principal-agent relationship in the first order has been considered inappropriate. Some studies consider the existence of multiple principals-Wood and Waterman $(1991,1993)$, Scholz and Wei (1986), and Moe (1987). However, these studies homogeneously address various principals and do not reach satisfactory solutions (including mathematical ones). The innovation in this approach, that is, the multilevel principalagent approach, is the indication of elements that facilitate the treatment (including qualitative treatment) of these relationships.

\footnotetext{
${ }^{1}$ The agency relationship is stated using the definition by Jensen and Meckling (1976, p. 364): "a contract where one or more people - the principal - engage another person - the agent - to carry out some task in their favor, involving the delegation of authority for the agent's decision-making."

${ }^{2}$ With respect to the limitations of this methodological perspective, see Schutz (1943) and Simon (1957), who present classical references of this discussion.

${ }^{3}$ For an expanded understanding of this theory, refer to Laffont and Martimort (2002).
} 


\section{CONTROL OF PUBLIC EXPENDITURES IN REPRESENTATIVE DEMOCRACIES: PRINCIPALS AND AGENTS DEFINE TH E ALLOCATION OF GOVERNMENT RESOURCES}

An established way of seeing and understanding the operation and benefits of representative democracy adopted through common sense and developed through widely accepted theoretical elaborations underlies the theory of action, in which the governing (elected) act in pursuit of collective interests (i.e., at the service of the (voters) who choose them in regular and periodic electoral processes to conduct public affairs). According to this vision, a budget allocation is the expression of a resource allocation decision made by people through their representatives in the law of means.

Among the action theories available, the principal-agent theory (with its economic background) has been increasingly used to elucidate the decision-making and implementation process of government policies in modern democracies. The central argument of the theory is that because all individuals seek to maximize their positions with the least-possible effort ${ }^{4}$, it is necessary to establish efficient punishment and reward mechanisms so a person placed at the service of another does not deviate from the latter's objectives and interests. That is, such a person does not take advantage of the privileged position he/she enjoys when conditions favor taking certain actions that are not always visible to his/her agent.

In the specific case of representative democracy, the principal-agent theory provides convenient explanatory bases to understand how elected rulers eventually decide and act in a way that addresses median voter expectations. From this perspective, elections are therefore moments in which voters punish or reward rulers and their parties at the end of a period of achievements (i.e., vertical accountability). In turn, mechanisms of checks and balances and systems of horizontal accountability are instruments for the principals' surveillance and control over the agents, serving as guarantees between election periods.

From a principal-agent perspective, the government's budgetary system and processes consist of arrangements and instruments through which public funds collected as taxes that cannot be evaded are used to benefit the community. Thus, the planning, implementation, and evaluation of the public budget occurs in accordance with procedures and standards involving the executive and legislative powers that divide technical and political responsibilities among themselves under the indirect supervision of the people ${ }^{5}$ through their legislators (and through ex-

\footnotetext{
${ }^{4}$ This theory is based on neoclassical economic thought and is fully compatible with the public choice theory known as the "economic theory of democracy." These two approaches that espouse the rational choice thesis are based on a vision of the world and of mankind in which selfishness is the defining element of individual decisions and actions. There is no reason to expect that when making a decision or taking an action, a person stops benefiting themselves in order to benefit a third party if they have the opportunity to do so; this includes the ruler, who is theoretically a guardian of collective interest.

${ }^{5}$ Direct popular control proposals for public expenditures and policies are currently taking shape in
} 
ecutive activity supervisors) and through specific bodies for auxiliary control (e.g., internal comptrollers and auditor courts).

The problem to be solved in the control of public expenditures in conventional representative democracies is ensuring that public agents (e.g., elected politicians and career bureaucrats and technocrats theoretically recruited on merit via public procurement) administer and manage resources to channel them to solve public, collective, or social problems. To solve this, the principal-agent theory proposes the institutionalization of controls that prevent deviations and punish those responsible when they occur. In other words, the theory recommends identifying the weak links in the chain of representation of interests and shielding the chain so it does not break. Jensen and Meckling (1976) propose the following: 1. Developing and structuring contracts between the principal and the agent; 2 . Monitoring the agent's activities by the principal; 3. Agent initiatives demonstrating that their actions are not harmful to the principals. These measures all imply agency costs that are added to similar costs arising from residual losses for the principals caused by agent decisions that are harmful to the principals.

The principal-agent theory has emerged in the business field to solve similar problems: in the corporate world, this theory holds between shareholders and managers hired mainly for senior management activities. Because of evident separation between direction and ownership in giant and diversified companies capitalized with the resources of millions of shareholders, there is a clear potential conflict between those making the daily decisions and those confined to providing resources to achieve them that seek returns in dividends and stock appreciation. This theory, which has led to agency costs and corporate governance issues fundamental to business management, has had various precursors: the perception of Commons (1931) about the use of transactional costs as an analytical unit of social activities; the separation between ownership and control pointed out by Beagle and Means (1932); and the modelling of company nature and social cost proposed by Coase $(1937,1960)$. These have all constituted a crucial research agenda in economics that started as a model with the classic works of Jensen and Meckling (1976) and Ross (1973), and, in empirical-confirmatory terms, with Morck, Shleifer, and Vishny (1988). The goal of this research agenda is to find appropriate and efficient forms to resolve the conflicts of interest that exist in the corporate field, which are very similar to those present in society's political relationships.

The use of the expression "governance" is no coincidence. Governance penetrated the business world, typical of competitive capitalism, where it was automatically set by the powers and competences of the old "captains of industry" (i.e., business leaders of small firms). These leaders provided a rational and maximizing

line with a deliberative semi-direct or in-depth democracy. There, ordinary citizens without elective mandates share decisions with the rulers and directly monitor their performance (e.g., in Brazil, this occurs in mechanisms such as participatory budgets and management councils for public policies). See Pires (2011). 
foundation for the predominant economic theory that prevailed between the last decades of the nineteenth century and the beginning of the twentieth century.

If there is a high degree of difficulty of establishing mechanisms of control of principals over agents at a reasonable and acceptable cost even in contemporary companies, it is almost impossible in democratic governments. In the latter, the number of principals and agents is greater, as is the complexity of the issues (i.e., most are irreducible to mathematically consistent cost-benefit calculations). Then, the interests in play are much more diffused. Nevertheless, giving up structures, systems, mechanisms, and procedures for the principals' control over agents is not possible for companies or for governments. In this manner, the challenge is to make both theory and the practice related to it more sophisticated in order to improve the relationships between leaders (corporate or governmental) and stakeholders (people, taxpayers, shareholders, and voters) in their good performance and reliability.

Among the criticism directed toward the principal-agent theory, it is worth highlighting the one that rejects its historical nature: its claim to explain by itself any and all situations in which there are agency relationships regardless of the objective, historical, and institutional conditions under which they occur. Thus, incorporating elements that relativize this analytic claim (typical of all rational choice economic theory) is a step that can improve its explanatory power to make it more realistic despite reducing its predictive power. This is because the result of each analyzed case will depend on idiosyncrasies never captured by the pure and abstract theory.

Monsma (2000) suggests that when considering the theory of action underlying the principal-agent approach to be "impoverished," it is "enriched" through the replacement of the single idea of rational choice with ideas of habitus and practical knowledge "combining ideas from Bourdieu (1977) and Giddens (1984)." For Monsma (2000), this methodology allows the principal-agent approach to assimilate the fact that "people do many things by force of habit or emotional impulses," that is, their behavior and choices do not always follow strict rationality. For this author, the issue is avoiding an "abstract model of action," adopting instead the "study of generating action" of a necessarily empirical nature. In this case, the contribution of Giddens (1984) lies in that he emphasizes the intentionality of action, whereas Bourdieu (1977) highlights the "provisions embedded in the body and feelings." The potential of this type of mixed approach to understanding past concretely verified agency relationships was demonstrated by Monsma (2000), in which he analyzed cases of successful Argentinean livestock farms in the nineteenth century.

Monsma's (2000) suggestion is promising for conducting an analysis of agency relationships existing within the budgeting process and the definition and implementation of public policies in the context of representative democracies. It concurrently allows the existing relationships to be considered of the principal-agent type (therefore carrying the potential conflicts of interest and behaviors that require control schemes with non-negligible agency costs), and it also allows these relation- 
ships to consider the specific conditions under which they are materialized within the budgetary institutional framework and the public policies in question.

The goal here is not to deepen this methodological discussion, but to adopt Monsma's (2000) proposal as a promising one. This suggests that in the case of empirical studies in the field of budgetary control and transparency, agency relationships are analyzed by considering the procedure he adopted with a multilevel vision or a principal-agent multilevel focus as reference. Thus, the stages of these relationships are considered as proposed later in this paper.

In addition to the prospect of extending the analysis to include multilevel agency relationships, we share Waterman and Meier's (1998) proposal to relax some restrictive aspects of the principal-agent model and advance to typologies and taxonomies that transcend the didactic character of the traditional approach. Using their considerations of the essential variables of the model-informational asymmetry and conflict of interests-Waterman and Meier (1998) outline two bi-dimensional arrays containing eight typical positions. The classic case of the principal-agent relationship is only one of these positions, as shown in Figure 1.

Figure 1: Typical situations in agency relationships

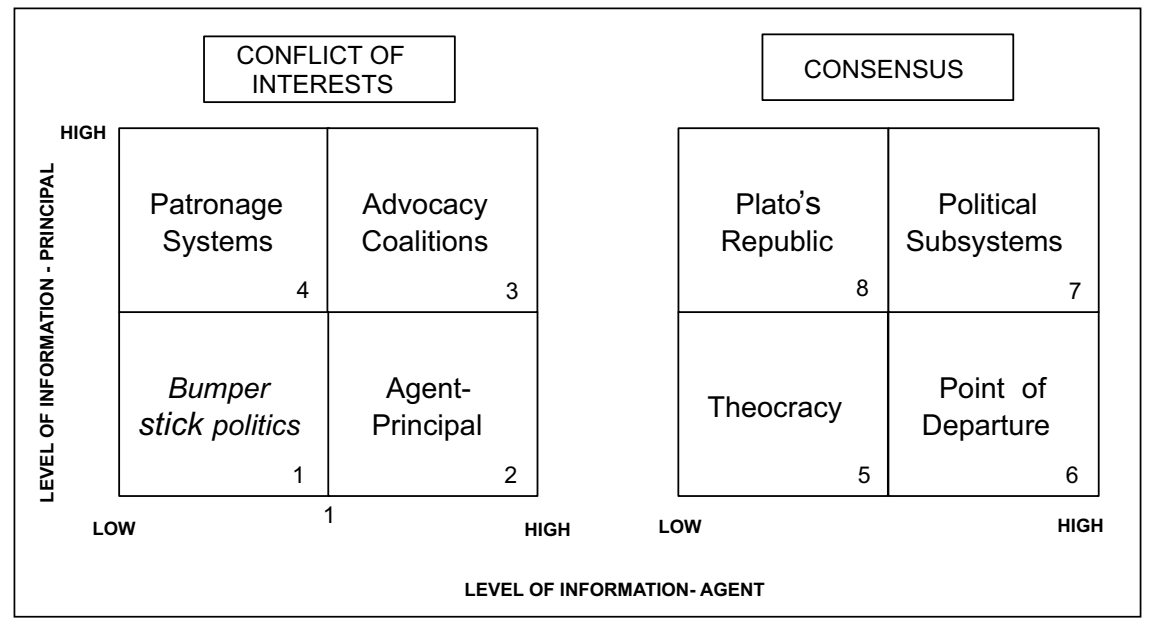

Source: Created by the authors from two distinct figures found in Waterman and Meier (1998).

Each level envisaged in the multilevel agency relationship is analyzed in a positional perspective with respect to Figure 1 as well as in relation to three distinct dimensions concerning what the position means in terms of informational connection. This is always important when it comes to contractual relationships, and the dimensions proposed for understanding this social connection are transparency, accountability, and responsiveness. Transparency is understood as a synchronous element for providing information on public deliberations, accountability is a judgment based on retrospective evaluation of the merit of public offerings, and responsiveness is a prospective emphasis on matching expectations for public policies and 
the offers made by the public authority ${ }^{6}$. In the three dimensions, there is a qualitative means of assessing relationships among schedules: those of the represented (demands for public policies) and those of the representatives (public policy offers).

\section{THE MULTIPLICITY OF AGENTS AND PRINCIPALS IN THE PROCESS OF DECIDING AND IMPLEMENTING BUDGETARY EXPENSES}

The principal-agent relationship between voters (principals) and elected (agents) in a representative democracy is not direct, as stated in the Lincolnian catchphrase "democracy is government of the people, by the people, for the people". ${ }^{7}$ It is mediated and comprises various levels and stages, each involving specific agency relationships in order to solve particular problems in the process for deciding and implementing public expenditures and policies. In this light (i.e., decomposed, multiple, and mediated), the principal-agent relationship in the budget process of a representative democracy allows the agents and principals historically and institutionally involved in it to be more easily identified. In turn, this provides and potentiates the historical and empirical analysis necessary for an in-depth understanding of the operation, results, and obstacles of the specific budgetary systems and processes. The type of analysis proposed by Monsma (2000) can thus be applied to each of the steps, that is, to each of the principal-agent relationships present in the budget process. Complementarily, they may be integrated to capture interactive elements in these relationships.

The following diagram is an attempt to map the fundamental principal-agent relationships involved in the budget process.

Between the choice of leaders conducted through election ballots (in which voters, i.e., the principals, choose the decision-making agents of the highest level) and the execution of works or the provision of services expected by citizens, there are several stages of decisions and actions that are the responsibility of different agents and groups of agents (which are also principals) in intermediary steps. As indicated by the rectangles in Figure 1, the electoral decision is crucial to the completion of projects and the development of governmental activities (as shown by the diagonal line connecting voters to projects and activities, as if they command the contracted employees and public servants). However, there are several enabling steps between the electoral decision and everyday government actions. Thus, a chain of principal-agent relationships is established with the following sequence:

1 . The voters, who are ultimately the principals, choose their strategic agents for leading the government, that is, the individuals responsible for operating the government apparatus in pursuit of the objectives considered by the elected. In this phase, all candidates and their respective parties appear as political agents, disput-

\footnotetext{
${ }^{6}$ Dimensions used for understanding the informational connection inspired by Pederiva (2012).

${ }^{7}$ From the famous Gettysburg Address delivered by Abraham Lincoln on November 19, 1863.
} 
Diagram 1: Steps of the principal-agent relationship

in budgeting in representative democracies

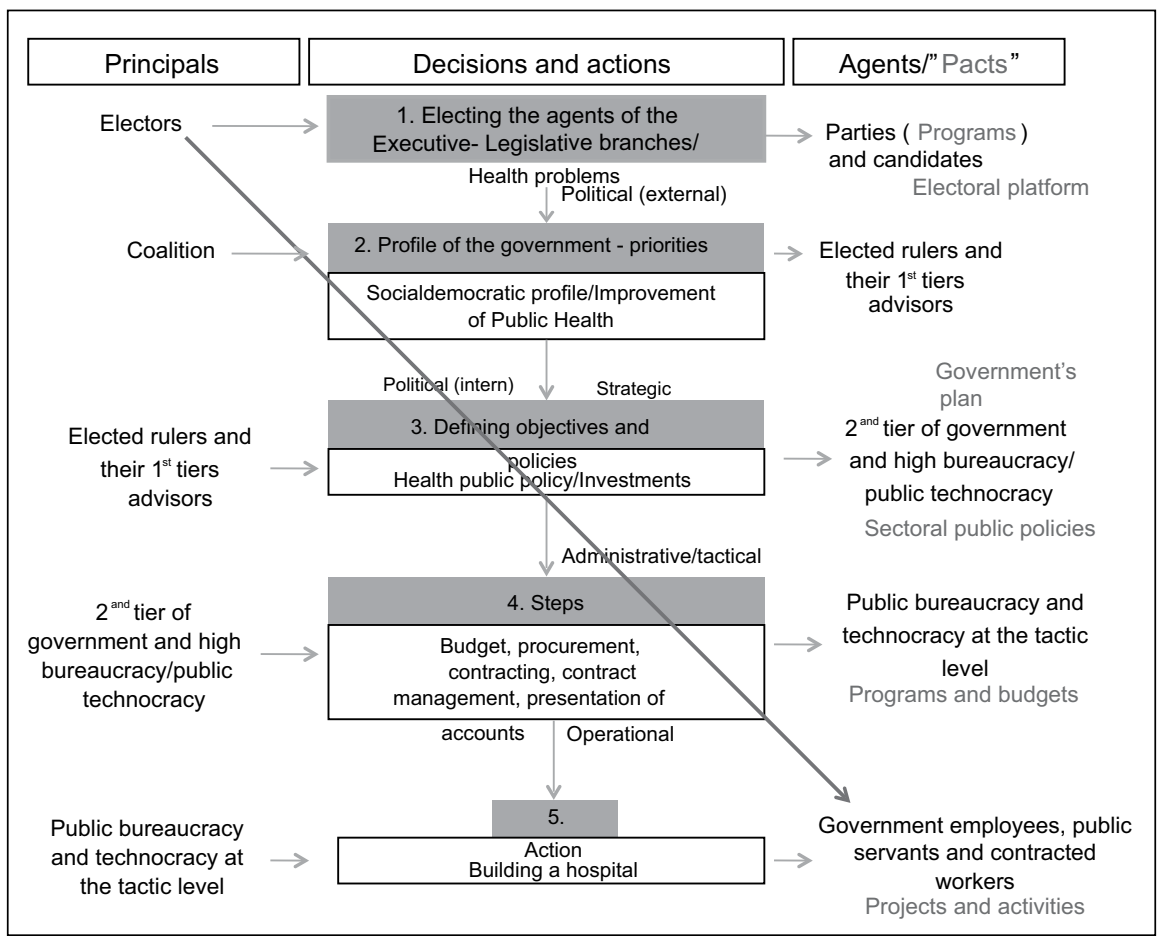

Source: Created by the authors.

ing the condition of government agents at the service of the voters. At this point, the party programs and electoral platforms act as the "contracts" that regulate agency relations. At this level, prior intervening factors are the quality of the party system (e.g., ideological and political sharpness, loyalty, and representativeness) and the quality of the electoral processes (e.g., competition/supply of candidates, voter profiles, and available information).

The situation described by the first level is typically one of conflicts of interest. The voter has interests (whether personal or collective) and politicians have (most critically) their reelection ${ }^{8}$ (Arnold, 1990). Therefore, the type of agency relationship is located in the typical situations of Quadrants 1, 2, 3, or 4 in Figure 1. When analyzing the information level, it is clear that the agent's (voter's) level of information is low, but the politicians' level of information is also low. The stance of one Brazilian parliamentarian is particularly emblematic of this, as he was elected with the following campaign motto: "Do you know what a congressman does? I don't know

\footnotetext{
${ }^{8}$ Political agents seeking re-election as their main objective has become one of the operational premises of political science in line with the economic theories of public choice, although it is acknowledged that there are politicians with various interests of a more altruistic nature.
} 
either. Vote for me and I'll tell you." Although this is an outlandish case, the complexity of the governmental apparatus makes it virtually impossible for the politician, in individual terms, to have a high level of information about its operation. Fenno (1966) demonstrates the long and painful learning process of North American congressmen who assume positions in the U.S. Congress' Appropriations Committee. The relationship can therefore be situated in Quadrant 1 (Q1) of Figure 1 (F1).

According to Waterman and Meier (1998), in this position, the informational factor has no relevance and can be disregarded. The aim is not to develop in-depth knowledge about subjects and issues, because these are treated in a superficial and caricatural way. A discussion on abortion, for example, becomes "women's absolute right" vs. "baby murderers." The party programs and electoral platforms, which should serve as contracts to govern agency relationships, become no longer important. Still, according to these authors, the role of bureaucracy becomes passive I such situations, where politicians work actively to promote self-implementable symbolic policies. Thus, the authors called this position "bumper-sticker politics," emphasizing that the negotiations on policies start from superficial and stereotypical ideological references.

The public budget generates very tenuous effects when we consider politicians who assume executive positions and virtually inexistent effects in the case of legislative representatives. The sole possible discussion arises between profligates and penny-pinchers, but few voters check the public deficit before voting'.

Accountability is a polysemic concept, but it is based on an informational component in all its aspects. However, at this level, it is argued that the information element is irrelevant such that accountability is inexistent in the traditional sense. As a synchronic provision of information about performance and deliberations, transparency also does not make sense, because past actions are judged retrospectively. The social connection element that is crucial at this level is therefore responsiveness ${ }^{10}$, which is understood as the expectation that public policies that are to be disclosed by the political actor (agent) are consistent with the collective preferences (signs of public opinion - principal), or (using economic terminology) that public supply meets public demand. In terms of the public budget, a candidate promising to reduce public expenditures is hoped to reduce public expenditures.

2. In the next step, the governing coalition that is formed becomes the principal, taking the rulers (understood as the elected and those they appoint in positions of trust) as its agents. The "contract" in effect becomes the government plan, and the first tier of government makes strategic decisions to implement it. Relevant factors at this level are the political preparation of ruling teams and their ability to

\footnotetext{
${ }^{9}$ Although it is acknowledged that voters are influenced by economic factors such as inflation (which may have its origin in public deficit), the causality is very indirect, justifying the somewhat peremptory assertion.

${ }^{10}$ Analyses of electoral behavior corroborate this view, as in Arnold (1990).
} 
match party interests in the coalitions. The ability to formulate and negotiate determines the capacity to respond to demands and pressures.

Unlike the first level, this is a situation in which there is a consensus of interests. The survival of the first-tier public leader, normally a position of trust, is directly linked to the principal's performance. In terms of information level, the situation is similar to the previous one: Politicians (principals) proceed with low information levels, and the first-tier leaders within the complex structures of governmental bodies do not have a high level of information although they occupy positions of trust and face resistance from the typical bureaucrat. The Weberian general rationalism of bureaucracy renders it autocratic and generates specific mechanisms of defense, primarily secret knowledge ${ }^{11}$.

Waterman and Meier (1998) call this position (Q5, F1) theocracy, because they consider that public policies are produced without political analyses ${ }^{12}$. They cite "drunk driving" as an example: everyone is against it, with politicians seeking ways to associate their name with the policy (see the term "credit claiming" by Arnold (1990) and Mayhew (1974)) and where bureaucracy acts as a "cheerleader"13.

Accountability is not important because the informational component is low for both the agent and the principal and because (as they are usually in positions of trust) the principal can get rid of the agent at any time dismissible ad nutum. Because the body of first-tier public leaders is typically not very large, this incidence of control is feasible ${ }^{14}$. Responsiveness loses its relevance, because the principal assumes the agent's full commitment to their public policy choices. In terms of social connection, the element of some relevance is transparency, with the agent's performance being monitored by the principal in real time ${ }^{15}$.

In budgetary terms, the relation is still not direct despite that allocative macro decisions take place at this level. However, the agent cannot take such decisions without the principal's opinion. These allocative macro decisions shape the public administrations' agenda and provide a measure of responsiveness between politician and voter at the previous level because they ensure that the public policies adopted are in tune with the signs of public opinion.

3. Then, those occupying second-tier positions enter the scene as agents imbued with tactical decisions and actions and working as links between the strategic level and the operational level. Now, the "contracts" are the general guidelines for pub-

\footnotetext{
${ }^{11}$ It is worth retrieving a quote by Weber (2000, p. 565): "Functionalism's most important means of power is the transformation of official knowledge into a secret knowledge, through the concept of 'professional secrecy': a means, in the last instance, to prevent control of the administration."

12 Public policies are therefore an article of faith.

${ }^{13}$ The authors call it thus because it considers that bureaucracy is in a passive situation - once the choice (policy) is made, they only provide support and promote it.

${ }^{14}$ In the case of the Brazilian Executive Branch, the 39 ministers are still a controllable group.

${ }^{15}$ With the increasing adoption of dashboards, management cockpits, and other government intelligence (GI) resources, the expression becomes literal.
} 
lic policies subordinated to the government plan and taking its items to a more detailed level. These have reached the budgetary field, and the next step is prioritization and costs. The most important skill at this level is the ability to link, which enables the transformation of ideas into operational proposals.

For the same reasons suggested in the previous level, there is also a situation of consensus of interests, as the second-tier leaders usually also occupy positions or functions of trust. However, in informational terms, while the principal (firsttier public leader) has little information, the agent already has a high level of information. This is the position that Waterman and Meier (1998) call the starting point (Q6, F1).

In this position, bureaucrats are technocrats, contracted for their expertise, that receive a task with a well-defined goal and have reasonable freedom to carry out their work as long as no disaster occurs. This situation results in the classic technician $v s$ politician antagonism. In terms of governance, the decisions and procedures are still complex (which determines the low information of the principals), but the construction of objective indicators is possible, allowing for the periodic monitoring of performance (fire alarm type: McCubbinse Schwartz, 1984).

Technocracy has an important budgetary role. It is a bridge between the operational and the strategic level, taking the final proposal for the allocation of resources to the upper echelons and bringing the decisions (with the necessary corrections) to the lower levels. To play this role, more information must be available.

Accountability is important because this level is already associated with the collective results obtained that are opposed to societal demands. The transparency dimension also becomes relevant, especially through indicators. Administrative activity is the process of realizing values laid down in a world of contingent facts. If the purposive is defined a priori (Levels 1 and 2), the administration is guided by facts. They may be concrete and historical, emphasizing present or probabilistic aspects, and indicating which global actions are able to make it conform with a pre-established purpose. This indicator interpretation exercise is, therefore, a specific type of reading of the world, and it may properly be exercised by bureaucratic institutions because it requires a division of labor and hierarchical control.

4. In the next step, the second tier of government is the principal group for career public agents that are responsible for making decisions and implementing actions to complete items from the government plan and keep the public machine in operation. Here, the programs, plans, and budgets are the "contracts," with their characteristically concrete clauses subject to quantitative evaluation when possible. Therefore, technical-scientific skill and a capacity for understanding are valuable.

At this level, there are again conflicts of interest, because two distinct groups are addressed: the traditional bureaucratic public servant and the occupant of a position of trust. In general terms, this is the level at which the discussion concerning the differentiation between State and Government policies begins to take place.

In informational terms, both the agent and the principal have a high level of information, placing the situation in Q3, F1, which the authors call advocacy coalitions. In this situation, the bureaucrat acts as a political agent - one among many. 
He cannot rely on technical expertise to prevail because he does not have an information monopoly. Waterman and Meier (1998) indicate that in such cases, it is common for coalitions to occur between agents and principals (i.e., second-tier bureaucrats and leaders), with currents aligned on each side of the issue: "in such cases information is important, but the politics is the politics of ideas and information is used in support of those ideas" (Waterman and Meier, 1998, p. 189).

At this level, there are resource disputes (with other coalitions of agents and principals), because this is where budgets, procurement, hiring, and contract management take place. Bureaucrats tend to establish a cooperative relationship with the principals whose proposals align with theirs and differ from those of their opponents, that is, "the enemies of my enemies are my friends."

After overcoming conflicts over resources and establishing the effective plan, accountability is a very important element, because the technocrat's (principal's) survival depends on the presentation of the result and the agent (career bureaucrat) has great power that is both informational and executive. For the same reasons, the dimension of transparency is also important, because it is at this level that the numbers are close to the moment when they leave the paper and take place in the world. The dimension of responsiveness is almost irrelevant, because both the command and the response are clear: given the result considered effective, expectations are restricted to the efficiency plan.

5. Finally, public agents at the administrative and managerial level are located at the bottom of the chain of principals, with the individuals and groups responsible for operational tasks as their agents. These can be public employees and/or those contracted through procurement processes. Operational capacity, savoir-faire, is key here.

At this level, contracting occurs through conventional legal adjustments: employment contracts, contracts between public administration, and private initiatives. In this situation, the principal has more information than the agent with the classic conflicts of interests: boss $v s$ employees; subordinates $v s$ superiors. The principals hold more information than the agents, who are almost exclusively operators. The bureaucrats (principals) dominate the situation by having both legitimacy and technical expertise. The agent does not need to have specific technical knowledge, and their actions are limited to strictly complying with what was commanded (in the case of office staff, strictly following the standard operating procedures). There is a tendency for the agent to serve as personal staff for the principal, which is why Waterman and Meier (1998) call this position Patronage Systems. Usually, the agent's entourage follows the principal when they change sectors ${ }^{16}$.

The dimension of accountability is important but very restricted, because it is directly verified by whether it was done or not done. The same goes for transparency, with the principal having direct control over what happens and continuously

\footnotetext{
${ }^{16}$ A situation verified among career bureaucrats, with several "grouplets" moving horizontally across the administration.
} 
monitoring the situation ("police patrols": McCubbins and Schwartz, 1984). Responsiveness is zero because expectations correspond to the certainty that it will be completed, with any deviations being automatically punished.

A practical example illustrates the argument of this chain of principal-agent relationships (as shown in Diagram 1): the construction of a hospital. Because this is a popular demand, voters (Level 1 principals) choose candidates with electoral platforms supported by party programs where public health is critical to their governmental agents (Level 1 agents). The formation of the ruling coalition (Level 2 principal) with a predominant social-democrat profile includes the resolution of public health problems (particularly hospital care) as a priority in the government plan. Thus, Level 2 agents (i.e., government members appointed as politicians and administrators responsible for health policies) are instructed to facilitate the work. Now as Level 3 principals, these politicians and administrators responsible for health instruct Level 3 agents (i.e., the administrative managers, who are usually career employees) to organize the actions necessary to carry out activities and implement projects. These, then Level 4 principals put the tactical- and operational-level bureaucrats and technocrats (Level 4 agents) into action. They then become Level 5 principals and initiate the operations necessary for carrying out the hospital's construction: budgeting, procurement, contracting, contract management, and presentation of accounts. The construction itself, under immediate control of the Level 5 principals, is carried out by the Level 5 agents: public employees in the construction sector of the government and/or construction company hired. In the end, if all links in the principal-agent chain are tight and well-connected among themselves, the people (having correctly chosen their government through elections) command civil construction companies or governmental bodies responsible for conducting works to provide public hospital facilities.

The last level contains the concrete results (a finished hospital) that climb the various levels and enters the reputational capital of the elected politicians (e.g., inaugurations and plaques) who use this result in their new campaign as a measure of their response to societal concerns. This sign influences the context and changes individual preferences (e.g., the topic of health can lose importance for the region that received the hospital). There become new preferences, which, revealed and aggregated, produce a new sign of societal demands, which in turn become the substrate from which the new public agents are selected.

Of course, as in the traditional approach, this cycle can be summarized as the principal's interests (public $\rightarrow$ personal values and interests $\rightarrow$ individual preferences revealed $\rightarrow$ signs of public opinion $\rightarrow$ selection of public agents) and the agent's interests (politicians $\rightarrow$ get mandates $\rightarrow$ create public policies $\rightarrow$ public policies revealed or public offerings $\rightarrow$ public policy implementation $\rightarrow$ collective results obtained). Its detailing and multilevel analysis, however, allows for a better understanding of the system's operation and dynamic, facilitating possible interventions.

Weak or poorly connected links break this linearity of command that the Level 1 principals have over the Level 5 agents (i.e., a discontinuity between the principal's decision and interest and the result of the agents' actions). In this case, 
historical and institutional analysis determines where the problems occurred, why, and the corrective measures. Certain characteristics of institutions and governmental organizations resulting from historical accumulations may stand out as structural elements causing political-administrative discontinuities. In the specific case of public budgeting, the standards, techniques, and procedures used may contain problems generating breaks in the links of the principal-agent chain that subordinates governmental actions to the collective interest.

Diagram 1 also registers that the decisions and actions of Levels 1 and 2 are political, where one is internal and the other is external to the government, respectively. The election of executive and legislative agents is of an external political nature: it occurs in the wider sociopolitical context, where actors from a given nation or community constitute its new government. The formation of the ruling coalition is of an internal political nature: the elected and the allies organize the government to decide and act. This Level 2 is within the strategic scope of governmental decisions: items such as management profiles, priorities, general lines of action, and sectoral policies arise from Level 2 decisions. Beginning with Level 3, we descend to the administrative-tactical (where the government's specific objectives and policies are defined and already thinking about how to conduct actions) and operational (4 and 5) space. Thus, it covers the entire scope of steps that the government needs to take in order to meet the popular will expressed at the polls: rulers are chosen and they organize politically and technically in order to govern, align the administrative structure to move in the desired direction, implement decisions, and develop operations. In the political sphere (Levels 1 and 2 in the Diagram), the conditions for democratic governance are established. In addition, Levels 3, 4, and 5 guarantee governance (of a techno-political nature according to Jensen and Meckling (1976): "a set of internal and external mechanisms for incentive and control that seek to minimize the costs arising from the problem of agency").

Ideally, an efficient and effective government is one whose good governability is combined with high governance, combining political and administrative conditions and appropriate management to decide and act. In the real world, this combination between governability and governance changes depending on what happens, and it is more stable in accordance with historical accumulations crystallized in institutions and government-society relationship patterns. The greater the governance of governmental organizations and the more solid the foundations of democratic governance, the more likely that the links in the principal-agent relationship chain are strong and firm, ensuring the fulfilment of promises from a government "of the people, by the people, for the people."

\section{FINAL CONSIDERATIONS}

The process of allocating public resources (budgeting) in representative democracies can be analyzed using the explanatory logic developed by the principal-agent theory, which was briefly presented in the first section of this essay. This approach, 
however, assumes rational-maximizing individuals in positions stripped of motivations other than strictly economic ones, making it vulnerable to criticism that suggests intervention of other factors in the decisions and actions involving public interests and resources. These interests and resources are subject to political debates that involve extreme visions of the world and defenses of viewpoints outside the scope of visions and actions of the simplified homo economicus presumed by the theory of rational choice. Moreover, these visions of the world and multifaceted points of view manifest themselves in specific historical contexts and institutional environments whose specificities must be considered. Then, the rationality of agents and principals, even if always considered maximizing and sufficiently rational and informed (which has been questioned by specialized literature since the work by Simons (1957)), is guided by elements of strategic thinking that may change considerably in each situation and before each set of incentives and institutional restrictions.

Thus, the efforts to include historical and institutional elements in the principal-agent approach are convenient for strengthening it as a theory and improving its use as a tool to support the understanding of socioeconomic reality and the solving of problems in representative democracy, public expenditures, and public policies. This essay is an effort in this direction that is limited to the field of public economy, specifically, the subfield of budget determination. This is created by highlighting the importance of unfolding the relationship between the elected representative (agent) and principal (citizen-taxpayer-voter) in the various steps to effectively place this agent at the service of its principal's interests. A chain of principal-agent relationships is articulated from the electoral process typical in representative democracies to achieve government activities that result in making public goods available to collectivities, as explained in the second section of this essay. Each link of this chain involves specific individuals (as agents and principals), institutional environments, and historical accumulations informing decisions, actions, interests, and visions of the world that should be considered in the political and management processes typical of the social control of public expenditures in representative democracies.

If one issue of the principal-agent model is to assume that the non-observable behavior of parts in contractual relationships are relevant, the type of qualitative analysis proposed might make the task easier. Improvements to the agency relationship classification along with the understanding of the social connection elements present in each level help explicitly reveal the utility function of the agent, allowing the principal to learn how to adjust their punishment and reward system.

The traditional model assumes the possible sequencing of events and activities in chains of means and ends and causes and effects. It also assumes a hierarchical configuration, where higher levels control the lower levels (roughly, the politician controlling the technician). In addition to these assumptions, there is enormous complexity around the real decision-making process with multiple actors, even if we consider that each one rationally pursues their own interests and is constricted only by others' search for individual interests. The multilevel approach allows for 
a better visualization of whom and how to charge. In the case of public policy implementation, the dyadic model is unrealistic and violates much of what is already known about the behavior of politicians and bureaucrats. In addition, the proposal is important for overcoming the strictly economic vision of the principal-agent model, incorporating institutional elements within it.

Thus, a vision of stricto sensu rational choice (whose theoretical contribution cannot be ignored as an abstract analytical model, despite its limitations) will be replaced by another vision of rational choice permeable to the idiosyncrasies of individuals, groups, and societies with regard to the operation of the possible social control of public expenditures in the context of historically and institutionally determined representative democracies. In the transition from one vision to another, a relationship between positive and normative aspects emerges that is marked by tensions, which cannot be previously predicted or remedied without using empirical elements. These, on one hand, reduce the predictive power of the conclusions that can be reached using this hybrid analytical instrumental. On the other hand, they qualify the conclusions it can lead to with a greater connection to reality.

\section{REFERENCES}

Arnold, R Douglas (1990) The Logic of Congressional Action, New York: Yale University Press. Bearle, Adolf, Means, Gardiner (1932) The Modern Corporation and Private Property, New York: McMillan.

Bourdieu, Pierre (1977) Outline of a Theory of Practice, Cambridge: Cambridge University Press.

Coase, Ronald H (1937) “The nature of the firm”, Economica, New Series 4(16): 386-405.

Coase, Ronald H (1960) "The problem of social cost", Journal of Law and Economics 3: 1-44.

Commons, John R (1931) “Institutional economics”, American Economic Review 21: 648-657.

Fenno Jr, Richard (1966) The Power of the Purse. Appropriations Politics in Congress, Boston: Little, Brown, and Company.

Giddens, Anthony (1984) The Constitution of Society: Outline of the Theory of Structuration, Berkeley: University of California Press.

Jensen, Michael, Meckling, William (1976) “Theory of the firm: managerial behavior, agency costs, and capital structure", Journal of Financial Economics 3(4): 305-360. Disponível em: <http://papers. ssrn.com/abstract=94043>. Acesso em: 21 set. 2013.

Laffont, JJ, Martimort, David (2002) The Theory of Incentives: The Principal-agent Model, Princeton: Princeton University Press.

Mayhew, David R (1974) Congress: The Electoral Connection, New Haven: Yale University Press.

McCubbins, Mathew D, Schwartz, Thomas (1984) “Congressional oversight overlooked: police patrols versus fire alarms", American Journal of Political Science 28(1): 165-179.

Mirrlees, James A (1999) “The theory of moral hazard and unobservable behaviour: Part I”, Review of Economic Studies, 66: 3-21.

Moe, Terry (1987) "Congressional controls of the bureaucracy: An assessment of the positive theory of 'Congressional Dominance'”, Legislative Studies Quarterly 12.

Monsma, Karl (2000) "Repensando a abordagem principal-agent: fazendeiros de gado e capatazes no século XIX”, Revista Brasileira de Ciências Sociais 15(43): 83-113.

Mork, Randall, Shleifer, Andrei, Vishny, Robert W (1988) "Management ownership and market valuation: an empirical analysis", Journal of Financial Economics 20(1-2): 293-315.

Pederiva, João H (2012) “Conexão orçamentária e responsividade democrática no Brasil de Lula e na 
Argentina dos Kirchner”, Tese (Doutorado em Ciências Sociais), Centro de Estudos e Pós-Graduação Sobre as Américas - Ceppac, Instituto de Ciências Sociais - ICS, Universidade de Brasília.

Pires, Roberto Rocha C (2011) Efetividade das Instituições Participativas no Brasil: Estratégias de Avaliação, Brasília: IPEA.

Ross, Stephen A (1973) “The economic theory of agency: the principal's problem", American Economic Review 62: 134-139.

Scholz, John T, Wei, Feng Heng (1986) "Regulatory enforcement in a federalist system", American Political Science Review 80: 1249-1270.

Schuetz, Alfred (1943) The Problem of Rationality in the Social World. In: Collected Papers, Vol. 2, The Hague.

Simon, Herbert A (1957) Models of Man: Social and Rational, New York: Wiley.

Waterman, Richard W, Meier, Kenneth J (1998) "Principal-agent models: an expansion?”, Journal of Public Administration 8(2): 173-202.

Weber, Max (2000) Economia e Sociedade: Fundamentos da Sociologia Compreensiva, Brasília: Editora Universidade de Brasília.

Wood, B Dan, Waterman, Richard W (1991) "The dynamics of political control of the bureaucracy", American Political Science Review 85: 801-828.

Wood, B Dan, Waterman, Richard W (1991) “The dynamics of political bureaucratic adaptation", American Journal of Political Science 37: 497-528. 